DOI: https://doi.org/10.15688/jvolsu4.2019.3.11

UDC $39(=512.211)$

Submitted: 25.04 .2018

LBC 63.5

Accepted: 20.11.2018

\title{
THE IMAGES OF THE ENERGY OF NATURE IN THE MYTHOLOGICAL REPRESENTATIONS OF THE NORTHERN SELKUPS
}

\author{
Olga B. Stepanova
}

Department of Siberia, Museum of Anthropology and Ethnography (Kunstkamera), Russian Academy of Sciences, Saint Petersburg, Russian Federation

\begin{abstract}
Introduction. The author considers the study of the traditional energy regimes of the Selkups according to mythology as the first priority. Methods and materials. Materials for studying the topic were taken from archival sources, scientific literature collected by the author during ethnographic expeditions. The methods used in the study include the analysis and use of the theory of myth. Analysis. The mythology of the Selkups describes energy figuratively. The main source of energy - heat and light - is the sun. It is drawn in the image of the old woman-ancestor who grants and takes people's lives / souls. The old woman, her huge gut, embodies the otherness, where, at the hour of birth, human souls come to the earthly world, and where they return after death. The images of the mythical old women embodying fire, moon, cold and night, are the incarnations of the mother sun. In these images, the energy of fire is classified into kind and terrible fire, the fire that gives life and brings death, into heat and cold, light and darkness. In addition to the energy of fire, Selkup mythology distinguishes the energy of water, land and forests. Its source and embodiment are also mythical old women-ancestors. This energy is described as food sent to men by the divine nature. Results. According to the Selkup mythology, the Selkups from ancient times recognized energy as the basis of human vitality and were well acquainted with all types and sources of natural energy used by humanity before the beginning of the era of technical inventions.
\end{abstract}

Key words: ethnography, Selkups, mythology, energy, images, history, reindeer breeding.

Citation. Stepanova O.B. The Images of the Energy of Nature in the Mythological Representations of the Northern Selkups. Vestnik Volgogradskogo gosudarstvennogo universiteta. Seriya 4. Istoriya. Regionovedenie. Mezhdunarodnye otnosheniya [Science Journal of Volgograd State University. History. Area Studies. International Relations], 2019, vol. 24, no. 3, pp. 126-136. (in Russian). DOI: https://doi.org/10.15688/jvolsu4.2019.3.11

\section{ОБРАЗЫ ЭНЕРГИИ ПРИРОДЫ В МИФОЛОГИЧЕСКИХ ПРЕДСТАВЛЕНИЯХ СЕВЕРНЫХ СЕЛЬКУПОВ}

\section{Ольга Борисовна Степанова}

Отдел Сибири Музея антропологии и этнографии (Кунсткамера) РАН, г. Санкт-Петербург, Российская Федерация

Аннотация. По данным селькупской мифологии, селькупы с древних времен признавали энергию основой жизненности человека и были хорошо знакомы со всеми видами и источниками природной энергии, которыми человечество пользовалось до начала эпохи технических изобретений. Энергию мифология 
селькупов описывает образно. Главным источником энергии - тепла и света - признается солнце. Оно рисуется в образе старухи-предка, дарующей и забирающей людские жизни/души. Старуха, ее огромное нутро, воплощает в себе инобытие, откуда в час рождения приходят в земной мир человеческие души и куда они возвращаются после смерти. Нутро старухи - мир огненной стихии, оно наполнено огнем и кипящей кровью; оболочкой старухиного живота служат раскаленные камень и железо. Образы мифических старух, воплощающих огонь, луну, холод и ночь, представляют собой ипостаси матери-солнца. В образах этих мифологических персонажей энергия огня классифицируется на добрый и страшный огонь, огонь, дающий жизнь и несущий смерть, на тепло и холод, свет и тьму. Души, выходящие из нутра матери-солнца, «сделаны» из того же материала, что и сама мать. Это лучи солнца, кровь, огненные камни, звезды и железные кости; каждый из этих образов выступает жизненной силой (энергией) заново пришедшего в земной мир человека. Помимо энергии огня, селькупская мифология выделяет энергию воды, земли и леса. Ее источником и воплощением также служат мифические старухи-предки. Описывается эта энергия как пропитание, посылаемое человеку божественной природой. Энергия ветра в фольклоре селькупов отмечена знаком опасности и смерти, но в виде шаманской силы она приносит пользу. Домашние олени - еще один источник энергии, называемый селькупским фольклором. Эта энергия имеет транспортное значение, а также используется для сохранения тепла телом человека.

Ключевые слова: этнография, селькупы, мифология, энергия, образы, история, оленеводство.

Цитирование. Степанова О. Б. Образы энергии природы в мифологических представлениях северных селькупов // Вестник Волгоградского государственного университета. Серия 4, История. Регионоведение. Международные отношения. - 2019. - Т. 24, № 3. - С. 126-136. - DOI: https://doi.org/10.15688/jvolsu4.2019.3.11

Введение. Данное исследование является частью большого проекта «Энергия Арктики и Сибири: использование ресурсов в контексте социально-экономических и экологических изменений». Проект направлен на исследование функционирования системы традиционного природопользования и жизнеобеспечения в условиях новой экономической формации России. В ходе введения различных инноваций в XX - начале XXI в. были разрушены устойчивые способы взаимодействия местного населения с окружающей средой, позволявшие ему оптимально использовать ресурсы, поддерживая систему жизнеобеспечения. Предполагается рассмотреть способы эксплуатации ресурсов местным населением в Арктике и Сибири в контексте функционирования современных проектов индустриального развития, рационализации хозяйственной деятельности и внедрения новых технологий и технических средств. Планируется проанализировать опыт использования альтернативных источников энергии, новых средств передвижения и их влияние на сложившиеся модели природопользования. До сих пор исследование энергетических процессов и анализ моделей традиционного природопользования в Арктике и Сибири рассматривались как две различные сферы исследований, слабо пересекающиеся между собой, проект нацелен на сокращение дистанции между ними.
Автор данной публикации участвует в проекте со «своим» народом - селькупами, и видит своей первоочередной задачей исследование традиционных энергетических режимов селькупов по данным мифологии. Мифология перечисляет издревле известные народу источники энергии и показывает, как они воспринимались народом и каким представлялось их использование.

Исследование не имеет хронологических рамок, поскольку рассматривает не историю формирования системы мировоззрения, а само мировоззрение, его отдельные аспекты. Можно лишь отметить, что традиционные представления селькупов начали уходить в прошлое в 30-е гг. XX в., на что оказали влияние социально-экономические преобразования и просветительная работа, проводившаяся среди селькупов советской властью.

Методы и материалы. Тема традиционного отношения к природным источникам энергии у селькупов по данным мифологии до сих пор не освещалась в научных трудах. Материалы для изучения темы были взяты из работ Е.Д. и Г.Н. Прокофьевых [17-22], Г.И. Пелих [11-15], энциклопедии «Мифология селькупов» [9] и т. д. В исследовании автор опиралась в первую очередь на собственные разработки по различным вопросам селькупского мировоззрения [24-33] и на свои полевые материалы, собранные во время экспе- 
диций в районы проживания северных селькупов. Определенные ориентиры в работе дали автору исследования Л. Уайта [35] и В.Н. Давыдова, В.В. Симоновой, Т.Ю. Сем, Д. Брандишаускаса [10].

К методам, примененным в исследовании, относится полевая работа среди современных селькупов (собирались материалы по традиционному мировоззрению, в первую очередь фольклорные тексты), анализ (в том числе с учетом некоторых теоретических закономерностей построения мифов), а также метод использования мифологических материалов для получения «практической» информации.

Анализ. Для традиционного мировоззрения любого народа характерно одухотворение сил природы, выражающееся в создании мифологических образов. Основным источником энергии - дающим свет, тепло и огонь - у селькупов признается солнце. Значение, которое селькупы придавали теплу, огню и свету в своей жизни, подчеркивается тем, что солнце и огонь воплощены в образы духов самого высокого ранга.

Главная фигура селькупского пантеона духов - священная «жизненная старуха» Илынтыль кота, мать всего сущего, дух-первопредок. Она хозяйка солнца и само солнце. Ключевая ее функция - давать человеку жизнь. Селькупы говорят, что солнце людей «содержит». На кончике утреннего луча-птицы солнце посылает на землю душу человека, которому суждено родиться. Солнечный луч - ильсат - 'то, что оживляет', жизненная сила $[21$, с. $66 ; 22$, с. 107]. Слово тельд - 'солнце' - селькупы переводят как 'солнце родившее'. Однако образ Ильнттыль кота амбивалентен - она не только дает человеку жизнь, но и забирает ее: родившемуся дарит колыбель, а умершему - гроб-колоду. Вторая сторона образа жизненной старухи выделилась в не очень отчетливый образ Ыльнтты кота подземной старухи. В амбивалентности образа солнца выявляются две различаемые селькупами категории солнечной энергии - дающей жизнь человеку и забирающей ее.

Образ солнца в мифологии селькупов соединяется с образом огня. «Солнце живо на нем огонь», «огонь живой, он растет, размножается, питается, умирает» [1, л. 10-12].
«Огонь имеет тело, глаза. Дрова - это его еда. Огонь в доме надо подкармливать, он ест все, что и люди» [9, с. 289-290].

Как и солнце, огонь имеет образ старухи (бабушки). В предании, записанном Е.Д. Прокофьевой, женщина-мать, ребенка которой обожгла искра костра, изрубила костер топором и залила его водой. Огонь потух во всех чумах стойбища. Замерзли женщины и дети. Бабушка-свекровь виновницы несчастья опустилась на колени над очагом и далеко внизу, в темноте разглядела старуху - «огня-пламени хозяйку» («кожа ее как огонь горит»). Хозяйка огня после долгих уговоров согласилась вернуть «всем семи родам людей» огонь, но при условии, что обидчица отдаст ей за это своего сына [20, с. 79].

Огонь в образе своей хозяйки контрастен и категоризируется на добрый и злой огонь. Хозяйка огня и добрая, и злая одновременно. Она присматривает за детьми в отсутствие дома их матери [9, с. 291], при помощи своих детей-костров она обогревает и кормит людей $[15$, с. 28]. «Тую имья (туй имья) - огонь-бабушка. Она добрая, хорошая. Огонь - живой, с ним разговаривают. Когда зажигают, просят тепла». Но «если она пожар в лесу, она злая» [31, с. 67]. Она может быть и беспощадно жестокой: «ни один смертный человек не может заглянуть матери огня в глаза и остаться в живых; под ее взглядом все обращается в уголь и в пепел» $[15$, с. 28$]$.

К огню, считают селькупы, следует относиться с почтением, уважением. Нельзя бросать в огонь мусор, шевелить его железными предметами, обходить его против солнца; запрещено смотреть на северное сияние («небесный огонь»), вешать над огнем «нечистые» предметы, например женскую обувь и т. п. Считается, что нарушение этих запретов может повлечь за собой несчастье, болезни. Запреты распространяются и на дрова - «пищу огня». Нельзя бросать дрова в местах, где люди могут через них перешагивать и этим их осквернять $[20$, с. 66].

Следующая категоризация амбивалентного образа солнца происходит в противопоставлении его образу старухи, олицетворяющей холод, осень и зиму, ярус вечной мерзлоты в модели Вселенной, ночь, смерть и луну [15, с. 9, 27]. Поскольку всякое противопоставле- 
ние объединяет, можно сказать, что эта старуха - то же солнце, но с другим знаком.

Солнцу в представлениях селькупов, действительно, приписываются два противоположных состояния (горячее/яркое и холодное/бледное), зависящих от его местоположения во Вселенной (над землей или под землей), во втором из этих состояний солнце отождествляется с луной. Так, у мифической матери-лосихи, за день обходившей всю землю и ночью спускавшейся в подземелье, на рогах растут солнце и луна $[15$, с. 9], то есть днем лосиха олицетворяет собой солнце, а ночью луну. По полевым материалам автора, вечером и ночью, а особенно длинной полярной ночью, земной мир становится миром духов. На его небо уходит дневное солнце, становясь ущербным, тусклым и зеленым, то есть луной. В одном из мифов солнце и луна - две дочери огненной старухи - одновременно выступают как два солнца - летнее и зимнее [12, с. 134]. По другому мифу, у земли есть две дочери, «две девки», у которых лица - огонь. Одна дочь - небесное солнышко, другая живет под землей, лицо у нее пылает зеленым огнем, она - луна и солнце покойников [14, с. $14 ; 15$, с. 29]. Описывая мир через противопоставление/объединение образов солнца и луны, селькупы разделяют энергию на свет и тьму.

Идея зависимости жизни и смерти человека от солнца и огня в мифологии селькупов расширяется до идеи круговорота жизни во Вселенной, цикличного перехода души человека, его жизненного начала, от инобытия к бытию. Инобытие и потусторонний мир при этом воплощает сама хозяйка огня и солнца.

Селькупы полагают, что «в земле огонь, там горячо» [1, л. 5]. По материалам Г.И. Пелих, огонь заполняет пространство шестого яруса подземного мира. Этот огонь поднимается по корням и стволу мирового дерева, поэтому на его ветвях вырастают вместо плодов огненные шары - солнца $[15$, с. 24] (что делает понятным образ «обугленного дерева», по которому герой одного из фольклорных текстов перелезает в иной мир [7, с. 299-301]). По материалам Е.Д. и Г.Н. Прокофьевых, место обитания старухи-прародительницы Ильнтыль кота связывается с «морем с кровавой водой» (озером, «красной речки берегами»), оно расположено в жаркой («где све- тят семь солнц») стране предков селькупов. В вертикальной модели Вселенной мир предков находится на самом последнем ярусе неба или подземелья, а в горизонтальной - в верховьях или низовьях реки $[17$, с. $370-371 ; 18$, с. $104 ; 21$, с. $58,60,68 ; 22$, с. 112$]$. В этом мире так жарко, что кольчуги борющихся героев спаиваются [21, с. 55-56]. Поскольку в модели Вселенной огненные миры маркируются «верхом» и «низом», можно сказать, что весь потусторонний мир, все инобытие селькупы представляют огненным. Мать-прародительница является хозяйкой огненного инобытия и, следовательно, его воплощением.

По сведениям Г.И. Пелих, в старинных селькупских преданиях и на шаманском языке солнце (женщина) называлось иунчи [11, с. 102; 14, с. 92]. Е.Д. Прокофьева и С.И. Ириков термин шунчи (сунчи, щянчь) трактуют как 'нутро', 'внутренность': сельчи сунчи дом «жизненной» старухи из семи (множества) комнат, нуш шуньчи - нутро неба [21, с. 57 , $65 ; 6$, с. 95]. Согласно одной из общих мифологических закономерностей, любое божество воплощается в главном своем атрибуте. То есть старуха-солнце может представляться ее же домом и огромной полостью. В этом представлении нет ничего необычного: в селькупской мифологии уже имеется четко выраженный образ матери-земли-лосихи, на спине которой живут люди, а в утробе расположен потусторонний мир.

Стало быть, инобытие в селькупской мифологической картине мира заключено в огромное нутро матери-солнца, заполненное огнем.

Верность этого вывода подтверждается материалами Г.И. Пелих. По данным Г.И. Пелих, мать огня Има-кота-лоза-птылоса (тюэмэ) - главная обитательница и хозяйка огненного мира, заключенного в каменно-железную «оболочку»: «Красное огненное море плещется между железными и каменными берегами. Железо этого берега раскалено докрасна, а камни пылают белым светом. Этот раскаленный, пылающий бело-красными огнями берег кровавого моря селькупы называют вэзон-корит» $[15$, с. 22, 27, 28, 68]. По мнению автора, данный фрагмент дает описание потустороннего огненного мира, находящегося в утробе матери огня. 
С хозяйкой каменно-железного огненного мира сочетается образ кузнеца. Кузнечным молотом и кузнечными щипцами священная мать разрубает/разделяет своих спаявшихся сыновей, когда в пылу битвы они поднимаются до яруса ее огненного мира [2, л. $98 ; 21$, c. 55-56; 22, с. 111]. В селькупской мифологии кузнецы «причастны к рождению новой жизни».

Имя солнечной старухи Ильнттыль кота переводится как 'вместилище жизни', 'жизненный мешок' [36, с. 13] - она посылает на землю для рождения человеческие души, из чего логично заключить, что нутро священной матери наполнено человеческими душами. Что они из себя представляют?

Один из уже называвшихся образов души - луч утреннего солнца. Только у той женщины, на которую упал луч утреннего солнца, рождается ребенок «с душой». Солнечные лучи имеют способность оживлять умерших. В нескольких фольклорных сюжетах тело убитого врагами героя кладут на белую оленью шкуру на солнечной стороне чума, утром, когда «солнце поднимается на высоту “ушек” (кончиков) лука, его первые лучи падают на убитого и оживляют его» [22, с. 107].

Иногда душа человека представляется звездой. Когда звезда падает с неба, человек рождается, а когда появляется на небе, умирает. Например, в космогоническом мифе «Кишкаль вэттыл» [33, с. 24] следы лыж замерзшего божьего сына превращаются в звезды, образуя Млечный путь. По-видимому, души-звезды связаны с той стороной матери-солнца или с тем солнцем, которое становится луной и светит ночью. Звезды - тоже «сгустки» энергии, имеющие связь с холодом и зимой.

Душа у селькупов отождествляется с кровью. «Потеря крови грозит смертью. Кровь - это жизнь» [22, с. 127]. В фольклоре богатырь Палны, когда тунгусы тяжело ранили его брата, дает ему выпить своей крови, потом камлает, и брат поправляется [9, с. 148 , 232]. До сих пор селькупы считают, что «кровью другого человека можно оживить умершего - шаман оживлял». Оленью кровь они пьют, когда болеют простудой. Кровь убитых животных селькупы стараются не пролить на землю, чтобы обеспечить им последующее воскрешение. Кровь связана с огнем. В сказке о хозяйке огня огненная бабушка, возвращая людям огонь, зажигает его кровью сердца человеческого сына [20, с. 79].

Считается, что с помощью крови можно связаться с хозяйкой зимы и холода и передать ей свои просьбы. Обряды, во время которых эта связь устанавливается, описаны в «Мифологии селькупов» [9, с. 147] и у П. Третьякова [34, с. 411].

На южноселькупском материале кровь имеет ясную ассоциацию с камнем. Из драгоценных камней - капель крови богатыря Дочь Земли делает ожерелье-оберег [16, с. 196; 23, с. 171-176]. Камень в представлениях селькупов - тоже форма инобытийной жизни и души человека. Многие герои селькупского фольклора, умирая, превращаются в камень [5, с. 21-22; 15, с. 65 ; 9, с. 246, 249]. Камнями-пауками (звездами-пауками) наполнено брюшко небесной матери-паучихи - одной из ипостасей жизненной старухи. Камнизвезды-пауки падают на землю и дают начало новой жизни [21, с. $63 ; 13$, с. $10 ; 15$, с. 18$]$.

Селькупы полагают, что внутри каждого камня есть огонь и что камни падают с неба. «Камень жив, в нем есть огонь» $[1$, л. 10-12]. «Бог бросает с неба большие камни. В камне есть огонь. В самом боге огонь. Как идет, за ним все загорается». "С неба падают звезды, камни. Днем падают - зажигают. Разного размера. Ночью тоже падают. У ненцев тоже были такие камни. Упал камень, когда я жила на Покольке. Упало далеко, но осколки попадали на чум». «Есть камень, из которого добывают огонь. Такой камень отыскать надо. По нему чиркнуть ватой. Такой камень найдут, - таскают как спички» [31, с. 68].

В представлениях селькупов все блага посылаются человеку с неба священной матерью. «Такие перелетные птицы, как гуси, утки, посылались Небесной старухой с неба. Она через небесную дыру бросала на землю птичьи перья, и они, долетая до земли, становились утками и гусями» [22, с. 118]. Бросание чего-то с неба (из разных побуждений) самый привычный для матери-предка способ контакта с землей. По данным Г.И. Пелих, солнце когда лучом, когда молнией бьет в злых духов - лозов, выползающих из-под земли. 
Если на небе гремит гром, «это солнце ругается на чертей по-своему» [12, с. 136]. Старики-селькупы рассказывали автору о старухе, которая живет на небе и ругается со своим стариком, - тогда она гремит своими сковородками, и от этого происходят грозы с громом и молниями. «Бог бросает с неба тищщз - гром, пули, стрелы. Бог этим стреляет в нижних людей - лосов». «Кэсыл кома - железная стрела. Гром и молнии без дождя это стрелы» [31, с. 71]. Стрелы-зародыши кава лозы - также представлялись душой человека $[13$, с. 64$]$. И.Н. Гемуев и А.И. Соловьев обнаружили у селькупов представление о посмертном воплощении человека в те стрелы, которыми он пользовался на охоте при жизни [4, с. 50].

Таким образом, луч солнца, звезда, кровь, камень и железная стрела - образы души человека, связанные с солнечно-огненной ипостасью матери-предка. Этими душами наполнено нутро священной старухи-прародительницы. Можно заметить, что «материал» каждой из душ соответствует «материалу», который образует огненное нутро, плоть матери-предка.

В образе огненного нутра матери-предка-кузнеца, очень напоминающего кузнечный горн, содержится явный намек на то, что человеческие души не просто там хранятся, а переплавляются, обновляются. Обновление неизбежное событие для людей, готовых родиться или находящихся при смерти, то есть переходящих границу этого и того миров, бытия и инобытия. Переплавляет и перековывает души сама мать-кузнец, это ее предназначение и функция. По Е.Д. Прокофьевой, кузнецы «причастны к рождению новой жизни». Они выковывают шаману «новое тело» металлические части его шаманского костюма $[19$, с. 342-375] - ребра, кости рук, ног, часто с пальцами и суставами. Церемония оживления новых шаманских атрибутов, в которой участвуют мать-предок и кузнецы, описана Г.Н. Прокофьевым [17, с. 370]. Л.А. Варковицкой была записана сказка, в которой кузнец, помогая мальчику-герою, снабжает его новым железным лицом и железной спиной [9, с. 148-150, 308]. В фольклоре селькупов есть сюжеты с обновлением скелета другими способами. Все это позволяет зак- лючить, что «железные души», которые селькупская мать-кузнец перековывает в своем огненном мире, - это человеческие скелеты. Без «кузнечной» характеристики матери-солнца, проявляющей ее функцию обновления душ (тел), ее образ был бы неполным, незаконченным.

Все та же жизнедательная старуха Итынтыль кота в представлениях селькупов выступает хозяйкой и воплощением реки и «животворящего» болота, в ее воле - посылать или не посылать людям рыбу и уток, нужных для пропитания. Ежегодно, весной, садясь первый раз в лодку, селькупы смачивают водой голову и, обращаясь к хозяйке воды/реки, говорят: «Ама (Имья), дай мне рыбы». Те же слова произносят, когда ставят сети. Этот «водный» образ жизнедательной старухи соотносится с образом Хозяйки леса (земли), всех лесных животных и птиц, дарующей селькупам охотничью удачу [37].

Образ стихии ветра, ледяного ветра и вихря у селькупов тоже представлен старухой и связан со смертельной опасностью, ветер «съедает» и «задувает» человека до смерти. Например, существует поверье, что если человек коснется вихря (закручивающего воронкой воду, песок или траву), он вскоре умрет. Чтобы спастись от вихря, нужно выставить перед собой нож или топор лезвием против его движения и сказать: «Мать-вихрь, остановись (мэркый-пальчый имия, утыряс)! а затем причитать: мол, я ничего плохого не сделал, за что на меня ты разгневалась, смени свой гнев на милость и т. д.» [31, с. 109]. Вместе с тем силу шамана селькупы измеряли силой его «ветра», возможностью «сдуть» с человека болезнь.

Согласно «энергетической концепции культуры» Л. Уайта, человечество вышло на новую ступень развития, когда приручило домашних животных и стало использовать их энергию в земледелии и транспорте [35]. Селькупы, перебравшиеся на Север в XVII в., ни оленеводства, ни коневодства, ни скотоводства не знали. К концу XIX в. у селькупов сформировалось крупностадное тундровое оленеводство (у единичных семей нижне- и среднетазовских селькупов) и мелкостадное транспортное таежное оленеводство (у верхнетазовских селькупов). Оба типа оле- 
неводства селькупов были транспортным оленеводством, имеющим вспомогательное значение [8].

Мифология называет два источника появления у селькупов оленей: оленеводство пришло к ним от ненцев в результате военных столкновений или было даровано богами (духами). В текстах о появлении оленеводства олень служит источником и критерием материального благополучия человека, но не имеет самостоятельного образа [24]. Тексты, где олени выступают действующими персонажами и воплощаются в художественных образах духов-помощников шаманов, образуют отдельную группу. Однако и в их образах обнаруживается вторичность: шаманские олени-духи родились от небесного духа, имевшего облик человекаконя с железными ребрами [15, с. 35-37], что также подтверждает заимствование селькупами оленя из других культур. В образах оленей-помощников шамана подчеркивается их сила и выносливость, быстрота, а также послушание.

Из оленьих шкур селькупы шили нюки для покрытия зимних чумов, постели и зимнюю одежду. В ряде сказок обыгрывается факт, что зимой человек не выживет без теплой меховой одежды и замерзнет, в частности, в сказке «Берестяная малица Ичи», уже упомянутом тексте «Кишкаль вэтmыл» и сказке о двух сестрах-швеях [3, л. $58 ; 33$, с. 24]. То есть, по данным мифологии, селькупы активно использовали скрытую в оленях энергию - для согревания и передвижения.

Фольклор селькупов также признает источником тепла и энергии всякое движение. В поучительном тексте «Иди вперед» [3, л. 53] дается практический совет, как себя вести, когда держишь свой путь на морозе: двигаться и идти, не делая остановок.

Результаты. Итак, по данным селькупской мифологии, селькупы с древнейших времен признавали энергию основой жизненности человека и были хорошо знакомы со всеми видами и источниками природной энергии, которыми человечество пользовалось до начала эпохи технических изобретений. Энергия в традиционном мировоззрении селькупов воспринимается и описывается образно. Главным источником энер- гии - тепла и света - признается солнце. Оно рисуется в образе старухи-первопредка, дарующей и забирающей людские жизни/души. Старуха, ее огромное нутро, воплощает в себе инобытие, откуда в час рождения приходят в земной мир человеческие души и куда они возвращаются после смерти. Нутро старухи - мир огненной стихии, оно наполнено огнем и кипящей кровью, оболочкой старухиного живота служат раскаленные камень и железо. Другие образы мифологических старух, связанные с жизнью/ смертью и огнем, нельзя назвать полностью самостоятельными - они представляют собой ипостаси матери-солнца. К ним относятся Подгорная мать, дублирующая некоторые функции солнечной старухи, «огняпламени бабушка», и старуха, воплощающая луну, зиму, холод и ночь, - антипод старухисолнца. В образах этих мифологических персонажей энергия огня категоризируется на добрый и страшный огонь, огонь, дающий жизнь и несущий смерть, на тепло и холод, на свет и тьму.

Души, выходящие из нутра матери-солнца, «сделаны» из того же материала, что и сама мать. Это лучи солнца, кровь (тоже связанная с огнем), огненные камни, звезды, а также железные кости, выкованные матерью-кузнецом в огненном мире. Каждый из этих образов души в представлениях селькупов является «сгустком» энергии или, говоря на языке селькупского фольклоpa, жизненной силой заново пришедшего в земной мир человека.

Помимо энергии огня, селькупская мифология выделяет энергию воды, ее источником и воплощением является все та же старуха Ильнттыль кота. Описывается эта энергия как пропитание, посылаемое божественной старухой человеку. Тем же образом представляется и энергия, которую дают человеку хозяйки земли и леса. Энергия ветра в фольклоре селькупов отмечена знаком опасности и смерти, хотя считается, что в виде шаманской силы она может приносить пользу. Еще один источник энергии, называемый селькупским фольклором, - домашние олени. Энергия домашних оленей имеет транспортное значение, а также используется для сохранения телом человека тепла. 


\section{СПИСОК ЛИТЕРАТУРЫ}

1. Архивные материалы Прокофьева Г. Н. // Архив МАЭ (АМАЭ). - Ф. 6. - ОП. 1. - № 9. - 41 л.

2. Архивные материалы Прокофьевой Е. Д. // Архив МАЭ (АМАЭ). - К-І. - Оп. 1. - № 18. 152 л.

3. Архивные материалы экспедиционной поездки н.с. отдела Сибири МАЭ О. Б. Степановой в Красноселькупский район Тюменской области в 2008 г. // Архив МАЭ (АМАЭ). - К-І. - ОП. 2. № $1870 .-78$ л.

4. Гемуев, И. Н. Стрелы селькупов / И. Н. Гемуев, А. И.Соловьев // Этнография народов Сибири. - Новосибирск : Наука, 1984. - С. 39-54.

5. Григоровский, Н. П. Описание Васюганской тундры / Н. П. Григоровский // ЗСОРГО. Кн. VI. -Омск, 1884. - С. 1-70.

6. Ириков, С. И. Словарь селькупско-русский и русско-селькупский / С. И. Ириков. - Л. : Просвещение, 1988. - 223 с.

7. Кастрен М.А. Сочинения в 2 т. Т. 2. Путешествие в Сибирь (1845-1849). - Тюмень : Мандрики, 1999. - $351 \mathrm{c.}$

8. Козьмин, В. А. Оленеводческая культура народов Западной Сибири / В. А. Козьмин. - СПб. : Изд-во СПбГУ, 2003. - 235 с.

9. Мифология селькупов. - Томск : ТГУ, 2004. $-380 \mathrm{c}$.

10. Огонь, вода, ветер и камень в эвенкийских ландшафтах / В. Н. Давыдов, В. В. Симонова, Т. Ю. Сем, Д. Брандишкаускас. - СПб. : МАЭ РАН, 2017.-196c.

11. Пелих, Г. И. Досамодийский тип жилища нарымских селькупов / Г. И. Пелих // УЗТГУ. Томск, 1966. - Т. 60. - С. 94-107.

12. Пелих, Г. И. К истории селькупского шаманства (по материалам солярного культа) / Г. И. Пелих // Труды ТГУ. - Т. 167. - Томск : Изд-во Томского ун-та, 1964. - С. 132-144.

13. Пелих, Г. И. Материалы по селькупскому шаманству / Г. И. Пелих // Этнография Северной Азии. - Новосибирск : Наука, 1980. - С. 5-70.

14. Пелих, Г. И. Происхождение селькупов / Г. И. Пелих. - Томск : ТГУ, 1972. - 421 с.

15. Пелих, Г. И. Селькупская мифология / Г. И. Пелих. - Томск : ТГУ, 1998.-79 с.

16. Плотников, А. Ф. Нарымский край / А. Ф. Плотников // ЗИРГО по отд. статистики. Т. Х, вып. 1.-СПб., 1901.-366 с.

17. Прокофьев, Г. Н. Церемония оживления бубна у остяко-самоедов / Г. Н. Прокофьев // Известия ЛГУ. Т. ІІ. - Л. : Изд-во Ленинград. ун-та, 1930. C. 365-373.

18. Прокофьева, Е. Д. К вопросу о социальной организации селькупов (род и фратрия) / Е. Д. Про- кофьева // ТИЭ. Новая серия. Т. 18. - М. ; Л. : Наука, 1952. - C. 88-107.

19. Прокофьева, Е. Д. Костюм селькупского (остяко-самоедского) шамана / Е. Д. Прокофьева // Сб. МАЭ. Т. 11. - М. ; Л. : Наука, 1949. - С. 335-375.

20. Прокофьева, Е. Д. Некоторые религиозные культы тазовских селькупов / Е. Д. Прокофьева // Сб. МАЭ. Т. 33. - Л. : Наука, 1977. - С. 66-79.

21. Прокофьева, Е. Д. Представления селькупских шаманов о мире (по рисункам и акварелям селькупов) / Е. Д. Прокофьева // Сб. МАЭ. Т. 20. М. ; Л. : Наука, 1961. - С. 54-74.

22. Прокофьева, Е. Д. Старые представления селькупов о мире / Е. Д. Прокофьева // Природа и человек в религиозных представлениях народов Сибири и Севера. - Л. : Наука, 1976. - С. 106-128.

23. Сказки нарымских селькупов. - Томск : Изд-во НТЛ, 1996. - 185 с.

24. Степанова, О. Б. Данные фольклора о происхождении селькупского оленеводства / О. Б. Степанова // Экология древних и традиционных обществ. Вып. 5. Ч. 2. - Тюмень : Изд-во ИПОС СО PAH, 2016. - C. 251-255.

25. Степанова, О. Б. «Огненная» ипостась матери-прародительницы селькупов / О. Б. Степанова // Труды ТОКМ. Т. XV. - Томск : Ветер, 2008. C. 218-226.

26. Степанова, О. Б. Злая или добрая: к вопросу о главном мифологическом образе селькупов / О. Б. Степанова // Омский научный вестник. 2006. - № 8. - C. 52-55.

27. Степанова, О. Б. Каменно-железная ипостась матери-прародительницы селькупов: к реконструкции мифологического образа / О. Б. Степанова // Археология и этнография Приобья: материалы и исследования : сб. трудов кафедры археологии и этнологии ТГПУ. Вып. 2. - Томск : Изд-во ТГПУ, 2008. - С. 176-186.

28. Степанова, О. Б. Мать-змея и образ духаохранителя в мифологических представлениях селькупов / О. Б. Степанова // Сибирский сборник-1. СПб. : МАЭ РАН, 2009. - С. 87-93.

29. Степанова, О. Б. Медведь как образ матери-предка и души человека в традиционном мировоззрении селькупов / О. Б. Степанова // Радловский сборник. - СПб. : МАЭ РАН, 2007. - С. 206-215.

30. Степанова, О. Б. Мифологический образ матери-дерева в традиционном мировоззрении селькупов / О. Б. Степанова // Археология, этнография и антропология Евразии. - 2007. - № 3. C. 115-118.

31. Степанова, О. Б. Традиционное мировоззрение селькупов: представления о круговороте жизни и душе / О. Б. Степанова. - СПб. ; Абакан : Петербургское Востоковедение : Издательский дом «Пантеон», 2010. - 303 с. 
32. Степанова, О. Б. Фольклор северных селькупов (полевые сборы 2004, 2005, 2008 гг.). Ч. ІІ / О. Б. Степанова // Материалы полевых исследованиЙ МАЭ РАН. ВЫП. 17. - СПб. : Изд-во МАЭ РАН, 2017. - С. 37-67.

33. Степанова, О. Б. Фольклор северных селькупов: полевые сборы 2004, 2005 и 2008 гг. / О. Б. Степанова // Материалы полевых исследований МАЭ РАН. ВЫП. 12. - СПб. : Изд-во МАЭ РАН, 2012.C. 5-31.

34. Третьяков, П. Туруханский край / П. Третьяков // ЗИРГО по общей географии. - СПб. : [б. и.], 1869. - T. 2. - C. 215-531.

35. Уайт, Л. Избранное: наука о культуре / Л. Уайт. - М. : РОССПЭН, 2004. -960 с.

36. Федорова, М. И. Представления о душе и бессмертии в духовной культуре селькупов : автореф. дис. ... канд. культурологии / Федорова Марта Ивановна. - СПб., 2010. - 25 с.

37. Brandisauskas, D. Leaving footprints in the taiga: Luck, Rituals and Ambivalence among Orochen reindeer herders and hunters in Zabaikal'ia, East Siberia. Berghahn press / D. Brandisauskas. - New York : Berghahn press, 2016. - 305 p.

\section{REFERENCES}

1. Arkhivnye materialy Prokofeva G.N. [Archival Materials of Prokofyev G.N.]. Arkhiv MAE (AMAE) [Archive of the Museum of Anthropology and Ethnography], F. 6, Op. 1, no. 9. 411.

2. Arkhivnye materialy Prokofyevoy E.D. [Archival Materials of Prokofyeva E.D.]. Arkhiv MAE (AMAE) [Archive of the Museum of Anthropology and Ethnography], K-I, Op. 1, no. 18. 1521.

3. Arkhivnye materialy ekspeditsionnoy poezdki n.s. otdela Sibiri MAE O.B. Stepanovoy v Krasnoselkupskiy rayon Tyumenskoy oblasti v 2008 g. [Archival Materials of the Expeditionary Trip of Siberia Museum of Anthropology and Ethnography Scientific Reference Department O.B. Stepanova in Krasnoselkupsky District of Tyumen Region in 2008]. Arkhiv MAE (AMAE) [Archive of the Museum of Anthropology and Ethnography], K-I, Op. 2, no. 1870.781 .

4. Gemuev I.N., Solovyev A.I. Strely selkupov [Arrows of Selkup]. Etnografiya narodov Sibiri [Ethnography of the Peoples of Siberia]. Novosibirsk, Nauka Publ., 1984, pp. 39-54.

5. Grigorovskiy N.P. Opisanie Vasyuganskoy tundry [Description of the Vasyugan Tundra]. ZSORGO [West Siberian Department of the Russian Geographical Society]. Omsk, 1884, vol. 4, pp. 1-70.

6. Irikov S.I. Slovar selkupsko-russkiy $i$ russko-selkupskiy [Selkup-Russian and Russian-
Selkup Dictionary]. Leningrad, Prosveshchenie Publ., 1988. 223 p.

7. Castrén M.A. Sochineniya v 2 t. T. 2. Puteshestvie v Sibir (1845-1849) [Works in 2 Vols. Vol. 2. Travel to Siberia (1845-1849)]. Tyumen, Mandriki Publ., 1999. 351 p.

8. Kozmin V.A. Olenevodcheskaya kultura narodov Zapadnoy Sibiri [A Reindeer-Breeding Culture of the Peoples of Western Siberia]. Saint Petersburg, Izd-vo SPbGU, 2003. 235 p.

9. Mifologiya selkupov [Mythology of the Selkups]. Tomsk, TGU, 2004. 380 p.

10. Davydov V.N., Simonova V.V., Sem T.Yu., Brandyshkauskas D. Ogon, voda, veter i kamen $v$ evenkiyskikh landshaftakh [Fire, Water, Wind and Stone in the Evenki Landscapes]. Saint Petersburg, MAE RAN, 2017. 196 p.

11. Pelikh G.I. Dosamodiyskiy tip zhilishcha narymskikh selkupov [Dosamodian Type of Dwelling of the Narym Selkups]. Uchenye zapiski Tadzhikskogo gosudarstvennogo universiteta (UZTGU). Tomsk, 1966, vol. 60, pp. 94-107.

12. Pelikh G.I. K istorii selkupskogo shamanstva (po materialam solyarnogo kulta) [To the History of Selkup Shamanism (Based on the Materials of the Solar Cult)]. Trudy TGU [Tomsk State University Journal]. Tomsk, Izd-vo Tomskogo universiteta, 1964, vol. 167, pp. 132-144.

13. Pelikh G.I. Materialy po selkupskomu shamanstvu [Materials on Selkup Shamanism]. Etnografiya Severnoy Azii [Ethnography of North Asia]. Novosibirsk, Nauka Publ., 1980, pp. 5-70.

14. Pelikh G.I. Proiskhozhdenie selkupov [Origin of Selkups]. Tomsk, TGU, 1972. 421 p.

15. Pelikh G.I. Selkupskaya mifologiya [Selkup Mythology]. Tomsk, TGU, 1998. 79 p.

16. Plotnikov A.F. Narymskiy kray [Narymsky Krai]. Zapiski Imperatorskago russkago geograficheskago obshchestva (ZIRGO) po Otdeleniyu statistiki [Notes of the Imperial Russian Geographical Society on Statistics]. Saint Petersburg, 1901, vol. 10, iss. 1.366 p.

17. Prokofyev G.N. Tseremoniya ozhivleniya bubna u ostyako-samoedov [Ostyak-Samoyeds' Ceremony of Reviving a Tambourine]. Izvestiya $L G U$. Leningrad, Izd-vo Leningradskogo universiteta, 1930, T. II, pp. 365-373.

18. Prokofyeva E.D. K voprosu o sotsialnoy organizatsii selkupov (rod i fratriya) [To the Issue of the Social Organization of the Selkups (Genus and Phratry)]. TIE. Novaya seriya. Moscow, Leningrad, Nauka Publ., 1952, pp. 88-107.

19. Prokofyeva E.D. Kostyum selkupskogo (ostyako-samoedskogo) shamana [Costume of a Selkup (Ostyako-Samoyed) Shaman]. Sbornik MAE. Moscow, Leningrad, Nauka Publ., 1949, vol. 11, pp. 335-375. 
20. Prokofyeva E.D. Nekotorye religioznye kulty tazovskikh selkupov [Some Religious Cults of the Taz Selkups]. Sbornik MAE. Leningrad, Nauka Publ., 1977, vol. 33, pp. 66-79.

21. Prokofyeva E.D. Predstavleniya selkupskikh shamanov o mire (po risunkam i akvarelyam selkupov) [Selkup Shamans' Image of the World (Based on the Drawings and Watercolors of the Selkups)]. Sbornik MAE. Moscow, Leningrad, Nauka Publ., 1961, vol. 20, pp. 54-74.

22. Prokofyeva E.D. Starye predstavleniya selkupov o mire [Selkups' Old Image of the World]. Priroda i chelovek $v$ religioznykh predstavleniyakh narodov Sibiri i Severa [Nature and Man in Religious Representations of the Peoples of Siberia and the North]. Leningrad, Nauka Publ., 1976, pp. 106-128.

23. Skazki narymskikh selkupov [Fairy Tales of the Narym Selkups]. Tomsk, Izd-vo NTL, 1996. 185 p.

24. Stepanova O.B. Dannye folklora o proiskhozhdenii selkupskogo olenevodstva [Folklore Data on the Origin of Selkup Reindeer Breeding]. Ekologiya drevnikh i traditsionnykh obshchestv [Ecology of Ancient and Traditional Societies]. Tyumen, Izd-vo IPOS SO RAN, 2016, iss. 5, part 2, pp. 251-255.

25. Stepanova O.B. "Ognennaya" ipostas materipraroditelnitsy selkupov ["Fire" Hypostasis of the Mother-Ancestor of the Selkups]. Trudy TOKM. Tomsk, Veter Publ., 2008, vol. 15, pp. 218-226.

26. Stepanova O.B. Zlaya ili dobraya: $k$ voprosu o glavnom mifologicheskom obraze selkupov [Evil or Kind: To the Issue of the Main Mythological Image of the Selkups]. Omskiy nauchnyy vestnik [Omsk Scientific Bulletin], 2006, no. 8, pp. 52-55.

27. Stepanova O.B. Kamenno-zheleznaya ipostas materi-praroditelnitsy selkupov: k rekonstruktsii mifologicheskogo obraza [Stone-Iron Hypostasis of the Mother-Ancestor of the Selkups: To the Reconstruction of the Mythological Image]. Arkheologiya i etnografiya Priobya: materialy $i$ issledovaniya: sbornik trudov kafedry arkheologii i etnologii TGPU [Archaeology and Ethnography of the Ob Region: Materials and Research. Collected Works of the Department of Archaeology and Ethnology of TSPU]. Tomsk, Izd-vo TGPU, 2008, iss. 2, pp. 176-186.

28. Stepanova O.B. Mat-zmeya i obraz dukhaokhranitelya $\mathrm{v}$ mifologicheskikh predstavleniyakh selkupov [Mother-Snake and the Image of the Guardian Spirit in the Mythological Representations of the Selkups]. Sibirskiy sbornik-1. Saint Petersburg, MAE RAN, 2009, pp. 87-93.
29. Stepanova O.B. Medved kak obraz materipredka i dushi cheloveka v traditsionnom mirovozzrenii selkupov [Bear as an Image of the Mother-Ancestor and a Human Soul in the Traditional Worldview of the Selkups]. Radlovskiy sbornik. Saint Petersburg, MAE RAN, 2007, pp. 206-215.

30. Stepanova O.B. Mifologicheskiy obraz materidereva $\mathrm{v}$ traditsionnom mirovozzrenii selkupov [Mythological Image of the Mother-Tree in the Traditional Worldview of the Selkups]. Arkheologiya, etnografiya $i$ antropologiya Evrazii [Archeology, Ethnography and Anthropology of Eurasia], 2007, no. 3, pp. 115-118.

31. Stepanova O.B. Traditsionnoe mirovozzrenie selkupov: predstavleniya o krugovorote zhizni $i$ dushe [Traditional Worldview of the Selkups: Ideas on the Cycle of Life and Soul]. Saint Petersburg, Abakan, Peterburgskoe Vostokovedenie, Izdatelskiy dom «Panteon», 2010. 303 p.

32. Stepanova O.B. Folklor severnykh selkupov (polevye sbory 2004, 2005, 2008 gg.). Chast II [Folklore of the Northern Selkups (Field Gatherings of 2004, 2005, 2008). Part 2]. Materialy polevykh issledovaniy MAE $R A N$ [Materials of Field Research of the Museum of Anthropology and Ethnography of the Russian Academy of Sciences]. Saint Petersburg, Izd-vo MAE RAN, 2017, iss. 17, pp. 37-67.

33. Stepanova O.B. Folklor severnykh selkupov: polevye sbory 2004, 2005 i $2008 \mathrm{gg}$. [Folklore of the Northern Selkups: Field Gatherings of 2004, 2005 and 2008]. Materialy polevykh issledovaniy MAE RAN [Materials of Field Research of the Museum of Anthropology and Ethnography of the Russian Academy of Sciences]. Saint Petersburg, Izd-vo MAE RAN, 2012, iss. 12, pp. 5-31.

34. Tretyakov P. Turukhanskiy kray. Zapiski Imperatorskago russkago geograficheskago obshchestva (ZIRGO) po obshchey geografii [Notes of the Imperial Russian Geographical Society on General Geography]. Saint Petersburg, 1869, vol. 2, pp. 215-531.

35. White L. Izbrannoe: nauka o kulture [Selected: The Science of Culture]. Moscow, ROSSPEN Publ., 2004. 960 p.

36. Fedorova M.I. Predstavleniya o dushe $i$ bessmertii $v$ dukhovnoy kulture selkupov: avtoref. dis. ... kand. kulturologii [The Imge of Soul and Immortality in the Spiritual Culture of the Selkups. Cand. cult. sci.abs.diss.]. Saint Petersburg, 2010. 25 p.

37. Brandisauskas D. Leaving footprints in the Taiga: Luck, Rituals and Ambivalence Among Orochen Reindeer Herders and Hunters in Zabaikalia, East Siberia. New York, Berghahn press, 2016. 305 p. 


\section{Information about the Author}

Olga B. Stepanova, Candidate of Sciences (History), Researcher, Department of Siberia, Museum of Anthropology and Ethnography (Kunstkamera), Russian Academy of Sciences, Universitetskaya Emb., 3, 199034 Saint Petersburg, Russian Federation, stepanova67@mail.ru https://orcid.org/0000-0002-2130-2695

\section{Информация об авторе}

Ольга Борисовна Степанова, кандидат исторических наук, научный сотрудник, отдел Сибири Музея антропологии и этнографии (Кунсткамера) РАН, Университетская наб., 3, 199034 г. СанктПетербург, Российская Федерация, stepanova67@mail.ru, https://orcid.org/0000-0002-2130-2695 